\title{
Corruption as a Barrier for Foreign Direct Investment
}

\author{
Rifat Hoxha, Ph.D.c. \\ Kosovo, Prizren \\ E-mail:. rifati_pz@hotmail.com
}

\section{Doi:10.5901/ajis.2013.v2n8p582}

\begin{abstract}
Corruption is a horrible negative phoenomenon which affects directly states economical development and every populations social prosperity. Corruption is found specifically in those states in transition and in those states that are dealing with unstable political stability. Seeing Kosovos current economical situation, which is not a glorified situation, and the obligatory need for foreing investments, $i$ find it reasonable to contribute through this work for solving this problem and to attract as much as possible foreign investitors.

In this work $i$ will try to answer these questions:

$\checkmark \quad$ In what kind of forms is corruption shown in Kosovo?

$\checkmark$ How is this phoenomenon affecting at foreign investitors?

$\checkmark$ How do we fight this phoenomenon and how do we attract these foreign investitors that are so important for our states development?

The main purpose of this work is my personal concern about Kosovos actual economical state and foreign investitors departure as a consequence of corruption. I will try to present some recommendations for the solution of this problem. For this work $i$ will insure researches from conversations with some local business, different official institutions and some compatriots who are interested to invest in Kosovo. I will try to give this work theoretical and practical values, and to make it as more convenient and feasible as possible for all those who are interested to give even the smallest help to fight the corruption in general and to attract Foreign Direct Investments in our country, as a good chance toward enhancement and states economical development.
\end{abstract}

Keywords: Corruption, Investment, Economy, Economical Development.

\section{Foreign Investments in Kosovo}

"With Direct Foreign Investments we understand the capital investments in economic subjects outside our country that intend to direct and control the enterpreneurship of these subjects", says (Berisha, 2000). Kosovo is an appropriate place to invest and it has a lot of subterranean fortune, but same as a lot of countries that are in transition, we dont have the financial and technological equipments to process and use these fortunes. Kosovos government is inviting and trying all the time to create appropriate conditions to other countries which has known Kosovo, to motivate they business to invest in Kosovo. Recently our country is being supported by Turkey in the economical field. Turkeys supportion is really important because as we know some turkish well-known companies are part of Kosovos projects as : Bechtel-Enka,that is building the Ibrahim Rugova highway, then the International Airport of Prishtina "Adem Jashari", which is the only one in Kosovo and it is managed from turkish company Limak-Lion, also the winner of KEK-s distribution is the turkish company Çalik- Limak. So, Turkeys supportion is present in every section, from the bank section then to the agricultural section, turism and at last the cooperation between Kosovo and Turkey has resulted with "the agreement for the protection of investments" and we wait soon for the agreement of the "Free Comerce" between Kosovo and Turkey. However Kosovo still needs foreign investments and this has to be achieved by presenting and creating the appropriate conditions to the foreign potential companies for investment which our country offers in different sections of economy.

\section{The importance of direct foreign investments in Kosovo}

The direct foreign investments have a very unique and specific importance for Kosovo takin into account the actual state of economy and the conditions in which the economical development of Kosovo has to be realised.

Even though the statistics show an increasment of Kosovos economy, the high scale of unemplyement, the lack of the function of factories and the lack of budget for capital investments in our country shows that we need to work hard to 
motivate foreign investments. (Kristo, 2002) says that: "In lack of self accumulation, through direct foreign investments, we assure the necessary capital for the realisation of different developmental projects". Foreign investments have an important role in the economical developmental of Kosovo, watching the lack of financial, technical and technological equipments. According to (Kristo, 2004), "The role of foreign investments is seen in the technological transfer which includes not only the insertion of softwers in the market, but also the technical and the habbits of its use."

Except the increasment of the number of employees, it is also important the advance of our employees and their preperation to work in our country with Europian standards. From these investments also the local companies can develope cooperating with these firms and by using them as an excample of work and modern managment and by practising that form of menagment in their companies.

According to (Musabeliu, Kërqini dhe Bejko, 2012), "Through practise of modern menagment the local companies increase their chance to entrance in the international market because the directors of the high levels increase the opportunity of companies success. "This can best seen from Kosovos governments projects for the building of the highway in which is working the foreing company "BECHTEL-ENKA SH.P.K" which except the high number of kosovarian employees,these companies have become the model of work and managment for a lot of local business. Watching the big importance of foreign investments in the economical development of our country, $i$ think it is time for our institutions to work more for the promotion of Kosovo as an appropriate state for investment which creates every condition for the attraction of foreign investitors.

\section{Factors that prohibit Foreign Investments in Kosovo}

Except the importance that direct foreign investments have in our country, we still have alot to do to create the appropriate conditions to attract these foreign investitors.

According to the report (Central Bank Of Kosovo, 2013), the financial crise in alot of countries in Europe, has affected in the decreasment of direct foreign investments in Kosovo. However, it is not only the global crise that has reflected in the decrease of investments. According to experts of economy, in this decreasment has contributed also the lack of law and the high level of corruption and organised crime.

During a conversation with compatriots who are known for their activity mostly in Germany and Switzerland i saw that exist more negative factors that are prohibiting their investments in Kosovo. The main factor which is prohibitin foreign investitors to choose Kosovo to invest their fortune, it is the high level of corruption and organised crime, because they dont want to risk their self and their money. Other negative factors are: high takses, political stability, unfaithful competition, high duties, the bad execution of laws to protect the investitors, problems with energy etc.

According to (Progress report for Kosovo, 2011) "Corruption in Republic of Kosovo, for five years of independence as a state, it is very diffused and its affecting very bad in the economic, politic and social stability". Corruption as a negative factor for investment, is being mentioned almost everyday from top brass of government, but they are not doing anything concrete to fight this phenomen. Concerning it is the fact that in every institution is being discussed for a high level of corruption, however, no one is being prosecuted for this and not knowing who is corrupted. According to (Latifit, 2011) all these facts impose the thought that "The country maybe by tolerating and not fighting the corruption, becomes a total corruptiv system, and this kind of crime not only "legalizes" it , but also protects the mecanisms of the state". The report of the Central Bank of Kosovo, shows that from the year 2011 until the end of the year 2012 foreign investments have decreased from $53.4 \%$. This decrease of foreign investments represent a very big preocupation knowing that alot of investitors are leaving Kosovo, while sendin their investments in neighbor countries of Kosovo.

Kosovos authority must engage and show as more political motivation as possible to fight corruption and organised crime, phenomenon which on contrary is being amplified in the north Kosovo. This phenomenon is reflecting bad in our contry, and prohibiting every process and the economic development from which depends the stability and the future of our country.

\section{How and when appears corruption in Kosovo}

Corruption as a negative phenomenon is very complicated, and it appears in every section of social-state section in our country. Almost in every institution of Kosovo you can meet very easy corrupted top brass. This is an ugly disturbing truth, but in my opinion it is even more disturbing that in one way Kosovos population accepts it and helps corruption to develop every day, while making a habbit to finish their duties by corrupting different officials. Recently it became almost legalized for business of Kosovo to apply on different projects and to calculate $10 \%$ for the officials, or else it was very difficult to 
win. As regards employment in public institutions, you can only watch how many people are hired by giving bribe and who have familiar persons in positions and how many are rejected even if they have the right criteria for the job. This shows that corruption and organized crime is suffocating the economic development of the country and it is the main reason which is putting away foreign investitors in Kosovo.

The most usual forms in which corruption appears in Kosovo are: taking bribe, the acceptance of different gifts in exchange of official services, officials taking profits from projects, the profits of fortunes, money purification etc.

According to the recent report of (Freedom House, 2013) the level of corruption in Balcanic places, especially in Kosovo has increased obviosly. From this report we can see that Kosovo needs a very strong dedication to fight this phenomenon in every institutional sector. There can be a cooperation between justice organs, police, civils by not only rejecting corruption but also by reporting it to the competent organs.

To fight the corruption in our country we are being supported also by international organisations that act in and outside the country, especially recently Eulexs mission, addresed in Kosovo from year 2008 that is competent and is monitorising the feasibility of law, is investigating and judging penal acts of corruption in Kosovo, that is caused from top brass of our institutions.

\section{Conclusions and recommendations}

By everything that is said we came in a conclusion that there are many factors that are prohibiting direct foreign investments in Kosovo. The main factors as corruption and organised crime that are prohibiting direct foreign investments in our country, are strongly advanced that has become very hard to fight it. Now that Kosovo needs urgently foreing investments and we know the problem why they became stuck, $i$ think, it is time that the government of Kosovo together with Eulex and other independent institutions to act seriously to fight the corruption and the organised crime to create safety and good conditions for foreign investitors.

Disturbing is the fact that in Kosovo you assume that international organisations that fight corruption are not doing their job by lasting their consecutive mandate and by rationalizing their posturing in Kosovo with the reason that they need to execute the law in our country.

I think that if there were a good motivation of these international organisations of anticorruption in Kosovo there wouldnt me to this negative phenomenon for our economy and society in general. This thought is because International Organisations of anticorruption have different experiences from other Europe countries that have crossed the transition, and they can easily use the same most succesful model of one of these countries, to help Kosovo for a healthy economical and political development.

We as a population need to become aware of one's self if we want to have a developed state and economy we shouldnt have corruption in our society, we need to bring or create a loyal judgemental process to fight this bad phenomenon that is suffocating our economical development. The lack of strategies to fight corruption is causing prohibitons and delays in defining and eliminating this phenomenon of our society, the neglection of the enormous number of cases is not so good for Kosovos future.

I think that the best thing that our government can do to support the Foreign Investments in Kosovo is to improve the general climate of investment, while offering services and by motivating foreign investitors to invest in Kosovo, while removing the duties for different investments in machineries that are brought from outside the country, while offering social lands with good conditions for investitors to invest for different factories, while making it safe and by protecting their investments, by reducing the takses in general for foreign investitors also for small local business because this way it will motivate companies to pay the takses, by holding on to the convenient politics and by promoting Kosovo as an appropriate and safer place to invest.

\section{References}

Berisha, S. (2000). Financat Ndërkombëtare, Prishtinë, Universiteti i Prishtinës, Fakulteti Ekonomik.

Kristo, I. (2002). Biznesi Ndërkombëtar, Tiranw, Libri Universitar, Shtypur "SHBLU".

Kristo, I. (2004). Biznesi Ndërkombëtar, Tiranw, Shtypur "PEGI".

Latifi, V. (2011). Politika Kriminal. Prishtinë.

Musabeliu, B., Kerqini, D., Bejko A., (2012). Menaxhimi Strategjik, Tiranë.

Raporti i Progresit për Kosovën, (2011).

RIINVEST, (2002). Investimet e Jashtme Direkte në Kosovë, Politika Ekonomike, Rrethina dhe Strategjia e Promovimit, Instituti per hulumtime zhvillimore. 
Banka Qendore e Kosovës. (2013, Qershor 01). Keq me investime të huaja. Retrieved from http://www.albinfo.ch /. Freedom House, (2013). http://www.ekonomia-ks.com/?page=1,11,355930 